\title{
African Responses to COVID-19: The Reckoning of Agency?
}

\author{
Amy S. Patterson ๑, Emmanuel Balogun $\odot$
}

\begin{abstract}
Although the COVID-19 pandemic had claimed over one million lives globally by late 2020, Africa had avoided a massive outbreak. Patterson and Balogun analyze pandemic responses by the Africa Centres for Disease Control and Prevention and various states collaborating with civil society. They argue that responses display forms of agency rooted in contextually relevant expertise, pan-African solidarity, and lessons learned about health messaging and community mobilization from previous health crises. Yet collaboration has not always been harmonious, as actors have adopted various approaches in their interactions with global health institutions and civil society partnerships, and they have actively debated the use of traditional medicine as a COVID-19 treatment.
\end{abstract}

Résumé: Bien que la pandémie COVID-19 ait fait plus d'un million de victimes dans le monde à la fin de 2020, l'Afrique a évité une épidémie massive. Patterson et Balogun analysent les réponses à la pandémie apportées par les Centres africains de contrôle et de prévention des maladies et par divers États collaborant

African Studies Review, Volume 64, Number 1 (March 2021), pp. 144-167

Amy S. Patterson is the Carl Gustav Biehl Professor of International Affairs at the University of the South in Tennessee. She is author of The Politics of AIDS in Africa, The Church and AIDS in Africa, Dependent Agency in the Global Health Regime (with Emma-Louise Anderson), and Africa and Global Health Governance: Domestic Politics and International Structures. She has published articles on health, religion, civil society, and gender in Africa. She was a Fulbright scholar to Zambia (2011) and Tanzania (2019-2020) and teaches on African politics and the politics of global health and development. E-mail: aspatter@sewanee.edu

Emmanuel Balogun is an Assistant Professor of Political Science at Skidmore College. $\mathrm{He}$ is the author of the forthcoming book Convergence and Agency in West Africa: Region-Building in ECOWAS (Routledge). He has published articles on institutional change and the role of regional organizations in the creation, coordination, and management of regional peace and security and regional social policy in Africa, with a focus on ECOWAS and the African Union. E-mail: ebalogun@skidmore.edu

(C) The Author(s), 2021. Published by Cambridge University Press on behalf of African Studies Association. This is an Open Access article, distributed under the terms of the Creative Commons Attribution licence (http:/ / creativecommons.org/licenses/by/ $4.0 /$ ), which permits unrestricted re-use, distribution, and reproduction in any medium, provided the original work is properly cited.

doi:10.1017/asr.2020.122 
avec la société civile. Ils affirment que les réponses montrent des mesures individuelles ancrées dans une expertise contextuellement adaptée, une solidarité panafricaine et des leçons tirées des messages sanitaires et de la mobilisation communautaire des crises sanitaires précédentes. Pourtant, la collaboration n'a pas toujours été harmonieuse, car les acteurs ont adopté diverses approches des institutions de santé mondiale et des partenariats avec la société civile et ils ont activement débattu de l'utilisation de la médecine traditionnelle comme traitement COVID-19.

Resumo: Apesar de, no final de 2020, a pandemia de COVID-19 já ter causado a morte de mais de um milhão de vidas em todo o mundo, África conseguiu evitar a ocorrência de surtos massivos. Patterson e Balogun analisam as respostas que os Centros Africanos de Prevenção e Controlo de Doenças e vários Estados, em colaboração com a sociedade civil, deram à pandemia. Segundo os autores, essas respostas revelam diferentes tipos de agencialidade, baseados no conhecimento especializado relevante para cada contexto, assim como em formas de solidariedade pan-africana e nos ensinamentos que as anteriores crises sanitárias permitiram obter quanto à comunicação dos temas da saúde e à mobilização das comunidades. Porém, a colaboração nem sempre foi harmoniosa, uma vez que os vários atores adotam modos distintos de se relacionarem com as instituições de saúde mundiais e as parcerias da sociedade civil, tendo sido ativamente debatida a utilização da medicina tradicional no tratamento da COVID-19.

Keywords: agency; COVID-19; African Union; civil society; international relations; epistemic community

\section{Introduction}

By late 2020, the COVID-19 pandemic, which began with the novel coronavirus that was first identified in China in December 2019, had caused over one million deaths and significant economic downturn worldwide. Assuming that Africa's health systems would be unable to engage in the surveillance, testing, and patient care needed to limit viral spread, in early 2020 health experts predicted a surge in COVID-19 cases in the region and widespread economic destruction (African Union 2020g). Discussions of Africa's ability to flatten the curve and socially distance emphasized characteristics such as the continent's youthful population, the informality of economic systems (and dependence on hands-on labor), and the lack of state capacity to enforce statesanctioned lockdowns (Mobarak \& Barnett-Howell 2020). The top academic journal Science also released an article with the headline "The pandemic appears to have spared Africa so far. Scientists are struggling to explain why" (Nordling 2020). These declarations reflected assumptions originating in the colonial era that Africans would be unable to meet the health and hygiene standards needed to combat disease (Graboyes 2015; Webb 2014). They also assumed the inability of African actors to respond with similar 
measures to those used in "developed" countries because of deficient standards of living or a need to choose between food and personal hygiene (Broadbent \& Smart 2020). Despite these views, some countries in Africa have been lauded for their effective and aggressive approach to the virus. Senegal, for example, created mobile labs to ramp up its testing capacity, with the ability to return results within a twenty-four-hour period (Shesgreen 2020). Liberia began providing COVID-19 screenings at the airport for travelers coming from countries with more than two hundred cases, while also adopting aggressive contact tracing measures soon after the World Health Organization (WHO) declared the virus a global pandemic (Maxmen 2020). African responses to COVID-19 reveal the dynamic, multifaceted nature of agency in the "tight corners" of international relations (Lonsdale 2000). Analyzing the actions of the Africa Centres for Disease Control and Prevention (CDC) and patterns with state-civil society collaboration, this article illustrates the deepening of creative and diverse forms of agency, many rooted in solidarity, norms of cooperation, and epistemic communities (Tieku 2013).

Responses to the pandemic must be positioned in the broader debate about Africa in international relations, particularly the tension between African actors as victims of exogenous forces or players in global processes (Brown \& Harman 2013). Agency is defined here to be the capacity of state and nonstate actors to act, react, engage with, ignore, speak, or remain silent in international spaces. Agency is purposive, but it is not always used for the emancipatory objective of "challeng[ing] the dominant material and ideational structures" (Hurt 2013:53). Purposive agents may act to preserve the status quo or to ensure their survival. Agency is dynamic and at times, aspirational, "a process of becoming, rather than a state of being" (Chabal et al. 2007:3). It can occur on many levels, because actors operate in various contexts, from the local to the global. As such, this analysis focuses on the agency manifested at the continental level, through the Africa CDC, and at the national level, through identified patterns of state-civil society collaboration.

This article's analysis is situated in a context with increasingly nationalist approaches to vaccine development by the United States and China, calls by many states and the WHO for greater collaboration, and limited donor attention to the disease in Africa (Picheta 2020; Lawler 2020; Editors 2020). During global disease outbreaks, cooperation can facilitate timely information sharing, exchange of expertise, and resource pooling (Youde 2012). African states compose almost one-third of United Nations (UN) member-states, and Africans serve in high positions in several UN agencies, including the Director General of the World Health Organization, Tedros Ghebreyesus. Despite Africa's participation in such institutions, attention to coronavirus in Africa during the pandemic's first few months was secondary to the focus on China, Italy, and the United States, mainly because of the virus's origins and initial spread. The United States and the European Union (EU), both major health donors to countries in 
Africa, did little initially in the region to address COVID-19. Echoing broader U.S. policy patterns that emphasize U.S. strategic interests over African concerns (Zeleza 2013; Westcott 2019; Schraeder 2018; Kohnert 2018), the United States placed a moratorium on shipments of protective equipment by the U.S. Agency for International Development (USAID) to aid partners. It then promised USD270 million for "risk communication, water and sanitation activities, infection prevention and control, and public health messaging" (Bertrand et al. 2020; U.S. Department of State 2020). The United States also withdrew from the WHO, blaming the organization for not criticizing China's delays in information sharing and undermining the WHO's ability to assist African COVID-19 responses (WHO-AFRO 2020a). The EU, facing its own internal divisions over sharing health supplies, was slow to respond in Africa. However, by July 2020, it supported the Africa CDC's testing and surveillance programs, as well as water and sanitation projects, and by September 2020, it had provided EUR10 million toward the implementation of the Africa CDC's Joint Continental Strategy for COVID-19 (European Union 2020). These actions fit within the EU's emphasis on stemming the tide of migration to Europe through health and development projects (Barigazzi et al. 2020).

Beyond U.S. and EU efforts, many global institutions collaborated with the Africa CDC, national governments, and civil society organizations. (We discuss the WHO efforts below.) By August 2020, the Global Fund to Fight AIDS, Tuberculosis and Malaria had provided USD1 billion in emergency funding, as it worked to help governments and civil society groups to mitigate the pandemic's effects on current AIDS, tuberculosis, and malaria programs (Global Fund 2020). The UN Development Programme (UNDP) collaborated with the African Union (AU) to assist civil society organizations and sub-regional organizations with risk communication and knowledge sharing to educate local communities (African Union 2020c). In addition, the UNDP worked with the AU and national governments to develop social and economic assessments and response and recovery plans (UNDP 2020). By August 2020, UNICEF had spent almost USD600 million globally to help children whose health, food security, and access to education had been compromised due to the pandemic (UNICEF 2020). In September 2020, the Africa CDC also partnered with Unitaid, the Gates Foundation, the Clinton Health Access Initiative, and the Foundation for Innovative New Diagnostics to provide 120 million COVID-19 rapid tests (African Union 2020b). These programs provide crucial assistance, and we mention these collaborations to demonstrate the myriad ways African actors have asserted themselves as major players in the global response to COVID-19. As such, our focus here is on the complexities, collaboration, and agency within the African CDC and the state-civil society nexus.

This article makes three important contributions. First, by focusing on agency in the fluid COVID-19 pandemic, we deepen the study of African actors in global health governance. ${ }^{1}$ Second, we illustrate an agency rooted in solidarity and emergent epistemic communities, and we posit that these 
patterns found in African regional organizations and through state-civil society collaboration matter for tangible health policies. We define this emergent epistemic community as the interpretive, constructed environment created by African actors who draw upon collective understandings of expertise, knowledge, causal beliefs, principles, and purposeful action (Haas 1992). We recognize that epistemic communities include more than just individuals with technical knowledge or scientific expertise, and that they are not monolithic entities; they are also contested arenas shaped by social forces (Adler \& Bernstein 2005). Third, we highlight how agency takes on multiple forms, and heterogeneous responses mean that African solidarity ebbs and flows. We do not underplay differences among African actors and their response to COVID-19 or overplay harmonization through the epistemic community of the Africa CDC. We recognize a dynamism conditioned by the changing nature of the pandemic itself.

Our analysis relies on primary source documents that elucidate broad patterns of state, civil society, and regional organization activities. These include Africa CDC reports, press releases, webinars, and Twitter posts, as well as similar sources from the West African Health Organization (WAHO). We use online news sources and government reports from select African states to gain a greater understanding of national-level dynamics. In addition, we turn to a significant body of interviews, focus group discussions, and observations from our years of research on health governance to verify our COVID-related observations. Emmanuel Balogun has conducted thirty-five interviews with officials at the Africa CDC and WAHO, as well as with government officials in Burkina Faso and Nigeria. Amy Patterson has conducted over one hundred interviews with government health officials, donor and international NGO officials, and civil society organizations in Tanzania, Ghana, Zambia, Liberia, and Uganda. The total fieldwork spans the years of 2011 to 2020, with lengthy periods in Ghana, Zambia, and Tanzania. In addition to informing this analysis, the fieldwork helped to facilitate relationships with individuals in Africa with whom we have been able verify our observations about COVID-19 responses. This analysis draws on these countries because they vary in geographic region, colonial history, level of political competition and freedoms, gross domestic product, and human development indicators (World Bank 2020; Freedom House 2020). They also vary in state-civil society cooperation on health, from more collaborative (Ghana and Zambia) to less (Uganda and Tanzania), and in their approaches to regional integration. Though not providing an exhaustive list of COVID responses, the case diversity helps us to generate conclusions on African agency in the COVID-19 era and allows us to illustrate multiple ways through which agency is manifested.

This article begins by contextualizing the characterization of African agency in the international relations literature. The second section then highlights initial reactions to the COVID-19 crisis among African states as they debated global travel concerns and prepared for cases. The third analyzes continental-level agency illustrated through the African CDC, and 
the fourth investigates four patterns of national-level agency found in various state-civil society collaborations. These last two sections examine how these actors have leveraged opportunities to share expertise and to build on their vast experiences with prior epidemic responses. At the same time, despite efforts toward harmonization, pandemic responses have differed from country to country, as illustrated by the issues surrounding the efficacy of herbal treatments (Adkins \& Smith 2020). The final section concludes with questions for future research.

\section{Contextualizing African Agency in International Relations}

Major theories of international relations have tended to marginalize Africa. Neorealism, with its focus on hard power, geopolitics, and security, and neoliberalism, with its emphasis on economic interdependence, have downplayed the continent because of its limited military power and its relatively small role in global trade. Even neo-Marxism, which outlines how global economic structures hamper African development, has minimized the agency of African actors in the face of structural rigidities (Whitaker \& Clark 2018; Dunn \& Shaw 2001). As a field, international relations has either viewed Africa to be "victimised, chaotic, violent and poor" (Brown \& Harman 2013:2) or a "politically empty space" (Morgenthau 1985:36).

This article provides a more nuanced picture, building on prior scholarship that demonstrates that African actors are not passive participants in the international realm. They use multiple pathways to shape and demonstrate their agency, at times creating, adopting, and contesting the norms and structures of the international system to gain influence, legitimacy, and resources (Ayoob 2002; Acharya 2011). African political elites may establish and then manipulate global connections to ensure regime survival or to shore up the power of their political faction (J. Phillips 2018; Taylor 2015; Clapham 1996). They selectively interpret aid agreements and recognize (or downplay) donor requirements to ensure continued funding streams (Barnes, Brown, \& Harman 2015), and they stress dependency to gain resources (Bayart 2000). In Malawi, for example, state and civil society leaders leverage informal ties through a form of "shadow diplomacy" to affect donors' decisions about health funding (Anderson 2018). Post 9/11, Ugandan president Yoweri Museveni prioritized the war on terror to gain U.S. support, while Rwandan president Paul Kagame emphasized his country's progress on gender equality to deflect attention from other human rights issues (Fisher 2013; Burnett 2008).

At the national and international levels, African states may rely on the principle of sovereignty-and its implied requirement that donors must work through national-level administrative processes-to dictate aspects of aid agreements with more powerful states (Brown 2012). Authoritarian Angola leveraged Chinese investment to skirt demands for democratic reforms from multilateral and OECD donors and to assure regime survival (Mohan \& Lampert 2012; Mohan \& Power 2013). African states have used international 
institutions such as the UN to "soft balance" against the United States and Western European states on issues of concern. This occurred when they opposed the establishment of the United States Africa Command in 2007 (LeVan 2010), and when they asked the UN Security Council to suspend the International Criminal Court warrant for former Sudanese president Omar al-Bashir (Du Plessis 2012). In addition, states have actively contested established global norms on democracy, human rights, and humanitarian intervention (Chipaike \& Knowledge 2018). For example, the AU condemned the invocation of the Responsibility to Protect as justification for the NATO airstrikes in Libya in 2011 (Du Plessis 2012). These examples illustrate agency across multiple scales of governance, and they show how a variety of African actors situate themselves within the international system. They provide context for the way that African actors approached the response to COVID-19.

To facilitate agency, African actors incorporate various strategies. One is reliance on distinct understandings of solidarity that are rooted in panAfricanism (Adler \& Bernstein 2005; Edozie 2017). This solidarity was evident when the chairperson of the AU Commission, Moussa Mahamat, along with President Muhammadu Buhari of Nigeria, President Paul Kagame of Rwanda, President Hage Geingbo of Namibia, and President Cyril Ramaphosa of South Africa, castigated U.S. President Donald Trump for his criticism of the WHO and its Director General Tedros Ghebreyesus for leadership in the COVID-19 response. By emphasizing solidarity and consensus building, the AU (and its subsidiary body, the Africa CDC) draws from pan-Africanism as a "cultural reservoir" wherein interdependence and rhetorical solidarity inform the perspectives and decisions of African actors (Clapham 1996:106; Murray-Evans 2015; Edozie 2017; Tieku 2013, 2017).

Another strategy evident in regional organizations is "hybrid paternalism," or reliance on complex, negotiated, mutually dependent, and yet competitive relationships through which institutional members strive to gain access to institutional resources, support, and legitimacy (Glas \& Balogun 2020; Murithi 2009; Tieku \& Hakak 2014). These processes may stress discourses of capacity building, the right to development, and norm protection in order to gain resources and global attention. However, they also reflect shared, like-minded, intersubjective ideas and practices that shape a collective approach to governance and, in this case, responses to global health crises (Acharya 2004; Glas 2018).

Third, actors may rely on emerging epistemic communities such as the Africa CDC that give legitimacy to expertise in the international arena. This specific epistemic knowledge responds to local experiences, is connected to societal concerns and practices, and is broader than mere technical skills. For example, one can point to how South Africa relied on the contact tracing strategies used to respond to HIV and tuberculosis, or the way that West African countries drew from lessons in the 2014-15 Ebola outbreak to respond to COVID-19. A focus on solidarity and epistemic communities does not mean that African voices are homogenous on health (or other issues). Rather, the epistemic community provides room for debate and adoption of 
different strategies, while still agreeing to the broader objectives of pandemic control and appreciating the region's shared experiences in the global arena.

Civil society organizations also may reinforce this shared knowledge and norms, deepening African solidarity and collective agency (Kohnert 2018). For example, organizations of people living with HIV in Zambia and Malawi have stressed the norm of a human right to health to gain free access to AIDS treatment (Anderson \& Patterson 2017:14). Civil society also may contribute to knowledge building, providing expertise that augments African voices regionally and globally. For example, South African AIDS organizations have shown how to deliver life-prolonging medications in low-income settings and non-Western cultural contexts (Mbali 2013). In these efforts, civil society organizations may collaborate with the state to deliver services, share information, and formulate development agendas (e.g., see Brass 2016).

African actors must continuously contend with a landscape in which transnational circuits of trade, investment, and migration link up with national priorities to affect their options (Mohan 2015; J. Phillips 2018:104). At times, their actions may seem to reflect a lack of choices in structures of exploitation (Carmody \& Kragelund 2016). However, such fluid situations create opportunities for creative forms of agency rooted in collective identity, shared knowledge, and solidarity between states and across statecivil society lines. The COVID-19 crisis presents one such moment.

\section{Initial Responses to the Virus}

When the COVID-19 crisis began, the initial effects on Africa seemed to reflect the continent's marginality within the international realm and its vulnerability to negative exogenous forces. Algeria confirmed the first case in the WHO Africa region on February 27, 2020, with Senegal, Nigeria, and South Africa quickly following. Even though experts predicted that the virus would quickly spread to Africa from China because of the exponential increase in Africa-China trade and migration during the last decade (Gilbert et al. 2020), most index cases in countries came from Europe. The slow pace of testing in the West, European governments' hesitancy in cutting international flights, and Africa's continued economic, social, and political ties with the former colonial powers contributed to this pattern. When it became apparent that travel between Africa and Europe by tourists, diplomats, and businesspeople was facilitating viral spread, social media posts (often written by youth on WhatsApp) termed the pandemic "coronialism" (Penney 2020). The wordplay on "colonialism" linked the virus to historical patterns of engagement with European states that brought exploitation, calamity, and death to Africans through colonial rule. The virus moved along trade routes that colonial powers established roughly five hundred years ago to the territories that these powers then claimed during the Berlin Conference of 1884-85. The modern tool of globalization-air travel-facilitated viral spread. When Tanzanians joked on social media that they would die of this "disease of globalization" even though they lacked passports, they were 
acknowledging global inequalities, highlighting the negative side of globalization, and using humor as a tool of agency. Their agentic discourse pointed to a basic inequality that had endangered their health-the ability of infected Westerners to travel to Tanzania while most Tanzanians lacked the basic document, let alone the funds, to travel abroad (university student, interview, Dar es Salaam, March 17, 2020). This discourse contrasted with a common, essentializing narrative that ascribes pandemics as originating in "less developed areas," traveling across national borders, and threatening the West (Penney 2020; Wald 2008).

Initial responses by African state leaders illustrated both heterogeneity and collective unity, showing the complexity and multi-layered nature of agency, and at times, an agency that promotes regime survival in the context of economic structural constraints and exogenous forces (Whitaker \& Clark 2018). One common response by African governments was to suspend flights to China, although not all states did so rapidly. Ethiopian Airlines publicly justified its continued services, saying it had rigorous health checks for entering passengers (Marks \& Dahir 2020). After pressure from Kenya and the Ethiopian public, Ethiopia cut some (but not all) Chinese routes (Kimeria 2020). African national airlines faced domestic pressure from health ministries to cut flights, yet some countries such as Ethiopia also have close economic and/or political ties with China, making such actions difficult diplomatically (Star 2020).

States also differed on evacuating their citizens (who were primarily students) from China. During early 2020, some countries such as Uganda and Kenya did not evacuate their citizens, although others such as South Africa did. The reasons for inaction varied from a lack of funds to charter planes, to fear that returning students could transmit the virus, to assertions that if the students became infected, they would be better off in China (Williams 2020). There was no harmonized, continental approach, partly because in the early months, African states faced different levels of public pressure about China-related travel and evacuations. Like leaders everywhere, African actors also faced a dearth of scientific information about how the virus spreads and who is most at risk.

Although they diverged on some initial actions, African actors also organized collective and strategic approaches on information sharing, and they supported the WHO response. African leaders issued various statements through social media, particularly Twitter, to update citizens on governmental responses. They participated in the WHO's social media challenge \#SafeHands to ensure that citizens complied with public health measures and guidelines. As indicated above, they also adopted a shared position on U.S. actions toward the WHO. The AU Commissioner Moussa Faki Mahamat tweeted that the U.S. decision to withdraw funding from WHO in May 2020 was "deeply regrettable" and that all countries had a "collective responsibility" to the WHO during the pandemic. This rhetoric appealed to the pan-African solidarity norm that African leaders should think, act, and speak collectively as Africans to represent the region's interests and identities. 
It also emphasized global norms of cooperation and pointed to U.S. hypocrisy (Al Jazeera 2020b; Bareebe 2018).

Africa's interactions with China around COVID-19 illustrate the dynamism of agency and highlight how the driving forces of regime survival and African solidarity may overlap and undergird agency. Facing dire shortages in health supplies, many African states graciously accepted the thousands of test kits, masks, and gloves that China donated (Asiedu 2020b). This provided additional opportunities for African states to leverage China's increasing role in health (over USD5 billion donated to Africa between 2000 and 2013) in order to gain some health resources from Western donors (see above). China's donations could also shore up regimes that faced criticisms over economic downturns (Shajalal et al. 2017; Campbell 2020), particularly in light of rising debt, the decline in trade with China, the global fall in oil prices, and shrinking economies. By the end of April 2020, the International Monetary Fund had approved over USD4 billion to twenty-four African countries for emergency financial assistance (International Monetary Fund 2020). Thus, attempts to leverage China's donations for greater financial support reflected an agency of survival. At the same time, African states demonstrated solidarity, particularly in mid-April 2020, when the AU responded to videos that showed Africans experiencing violence and discrimination in Guangzhou because local people suspected they had re-introduced the virus into China. The AU condemned the racist actions and emphasized human rights norms of dignified and equal treatment, while many African countries issued separate statements that reiterated these themes (Asiedu 2020a). The incident provided opportunities to use China's hypocrisy over global south-south cooperation, as well as U.S. rhetorical support to Africa over the incident, as strategic leverage (Reuters 2020a).

\section{The Africa CDC: Solidarity and Debates within an Emerging Epistemic Community}

Actions of the Africa CDC illustrate an agency rooted in harmonization and coordination, with the latter resting on the recognized need for global solidarity and a specialized, technical response at the continental level (Nyabiage 2020). The development of and investment in specialized and technical expertise housed in regional institutions, such as the Africa CDC and the specialized health organization of the Economic Community of West African States (ECOWAS), WAHO, facilitate harmonization. These regional and sub-regional organizations work with the WHO, which provides technical guidance, preparation, coordination, resource mobilization, communication strategies, training for health-care workers, and transparent research processes for vaccines, therapeutics, and diagnostics (WHO 2020b). Such efforts build on pre-COVID-19 partnerships between donors and African health institutions that have addressed issues such as health system financing and universal health coverage (government health official, interview, Dodoma, January 30, 2020). However, although the WHO partnership 
contributes to harmonization and capacity building, it has not been without some tensions. For example, Burundi ordered the expulsion of a WHO expert team from the country days before its 2020 election, accusing the WHO officials of "unacceptable interference in [the health ministry's] management of the coronavirus" (Guardian 2020). After the election, and the death of former president Pierre Nkurunziza, collaboration improved, indicating how personal and domestic political considerations can affect global solidarity on health.

Cooperation through regional organizations reflects African experiences with overlapping health crises such as cholera, Ebola, and malaria (Balogun forthcoming). The Africa CDC has consciously drawn from lessons learned from these crises to guide the COVID-19 response and structure partnerships with external stakeholders. Following the West African Ebola outbreak, ECOWAS acted on recommendations from WAHO in 2015 to create the ECOWAS Regional Centres for Surveillance and Disease Control (ECOWAS RCSDC). This action hastened the establishment of the Africa CDC in January 2016, which then opened in January 2017 (Africa CDC 2020). The creation of these specialized agencies was a direct reaction to the slow response by African states to Ebola and other health crises, as well as the need to improve the quality and quantity of information about health preparedness and risk response capacities of African countries (interview, official, Department for Disease and Epidemics Control, Bobo-Dioulasso, August 18, 2018). The novel coronavirus has led these new institutions to play a significant role in the continent's response.

The multi-faceted, harmonized response of the Africa CDC is manifest in several actions. First, on February 22, 2020 (one week after the first reported case in Egypt), the Africa CDC developed a COVID-19 Joint Continental Strategy with three pillars: limit transmission, prevent deaths, and limit harm (African Union 2020d). The effort emphasized coordination, cooperation, collaboration, and communication, all elements of a harmonized approach. This strategy relies on the African Union's political, policy, and advocacy capacities to foster high-level political engagement; it has led the Africa CDC to train health-care workers in laboratory diagnosis, disease surveillance, infection prevention control (IPC), risk communications, and clinical care (African Union 2020d).

Second, the Africa CDC worked closely with the WHO to launch the Partnership to Accelerate COVID-19 Testing (PACT): Trace, Test, Track (CDC-T3), an initiative that seeks to strengthen testing capacity across the African continent, particularly in countries with minimal capacity. Endorsed by the Assembly of Heads of State and Government of the African Union, the partnership focuses on standardizing and deploying common technology platforms to improve public trust in testing. The organization has purchased test kits and distributed them to more than fifty countries (African Union 2020e). It also has established warehouses and distribution hubs and supported the testing of over one million Africans within a six-month period. Testing results guide case management and contact tracing programs 
(African Union 2020d). In addition to PACT, in March 2020, an African Task Force for Coronavirus was created between the Africa CDC, WAHO, and WHO to increase the number of laboratories equipped with COVID-19 testing capabilities. As of September 2020, almost fifteen million COVID-19 tests have been conducted across Africa, and the continent was on pace to conduct twenty million tests by the end of October 2020.

Third, the Africa CDC has worked with the private sector to promote testing. It distributed test kits and IPC supplies from the Jack Ma Foundation to all AU member states, and it collaborated with the Mastercard Foundation to deliver one million test kits and support ten thousand health-care workers at the community level (African Union 2020a). As mentioned earlier, the Africa CDC is also partnering with Unitaid, the Gates Foundation, and the Clinton Health Initiative on the development of rapid tests (African Union 2020b). Working with major corporations has increased resource access and agency for member states, though the broader objectives of these companies, many of which are headquartered in the global North, are unclear.

Fourth, as part of its efforts to prioritize knowledge sharing, the Joint Continental Strategy emphasized the creation of a regional knowledge hub called the COVID-19 Clinical Community of Practice. The hub consists of over eight hundred medical practitioners, academics, and other healthfocused clinicians, most from the African continent. It provides real-time COVID-19 updates, a vehicle for sharing peer-reviewed scientific literature, and opportunities for practitioners to collaborate to build health worker capacity (WHO 2020a). In addition, as outlined under the Joint Continental Strategy, the Africa CDC is developing and disseminating policy guidance documents and conducting regular briefings to the AU policy organs, AU Commission, and media. These policymaker briefings guide decision making and policy responses. The Africa CDC holds weekly webinars to share information on surveillance, IPC, and case management.

Fifth, to facilitate knowledge sharing, the Africa CDC organized a virtual conference in June 2020 on Africa's role in the development of and access to COVID-19 vaccines. This resulted in the AU Commission launching the Africa CDC Consortium for COVID-19 Vaccine Clinical Trial. The initiative strives to include African scientists and healthcare workers in vaccine development, and it is rooted in the recognition that a vaccine is a crucial step to achieve the three strategic goals of limiting transmission, preventing deaths, and limiting harm (African Union 2020f). These efforts legitimize African scientific knowledge and its contributions to a global pandemic, and they actively foster the construction of an epistemic community that is not rooted solely in the material interests of dominant states. They also stress an agency that is localized to meet the demands and challenges of the African context. While the Africa CDC has been successful in leveraging relationships with global health actors within and outside of Africa and fostering cooperation between African states, the limits of its capacity to act lie in the fact that it is a relatively new institution within the AU. Its capacity to improve the structural conditions that plague fragile health systems across the continent still 
remains to be seen. Despite this, the Africa CDC activities seek to eschew selfserving, self-interested behaviors in the response to COVID-19, and instead seek to empower African governments to rely on collective action and solidarity as the model response to the pandemic.

This is not to say that a shared approach promoted by regional organizations always implies harmony or homogeneity among all players. In May 2020, for example, Tanzania, seemed to shun regional cooperation, noticeably missing meetings of the East African Community and Southern African Development Community that were intended to develop a coordinated, subregional pandemic response (Houttuin \& Bastmeijer 2020). Even epistemic communities, although rooted in collective understandings of expertise, knowledge, and purposive action (Haas 1992), can be arenas of contestation as actors provide various knowledge interpretations and power shapes actors' relationships (Rushton 2015). This contestation, as well as the emphasis on localized and contextually relevant approaches to health, became apparent in May 2020 when officials in Madagascar announced the development of Covid-Organics (CVO), a "preventive and curative remedy against COVID19" (Al Jazeera 2020a). According to Malagasy president Andry Rajoelina, CVO is an herbal treatment that allegedly contributed to the recovery of 105 COVID-19 patients in Madagascar. After the announcement, Tanzania, The Gambia, Guinea-Bissau (which purchased the medication to distribute in other West African countries), Liberia, Democratic Republic of Congo, the Republic of Congo, Central African Republic, and Equatorial Guinea purchased the remedy, while Nigeria and Senegal committed to accepting CVO shipments from Guinea-Bissau and agreed to subject the therapy to standard pharmaceutical testing and validation (Africa News 2020b). South Africa also committed to assist with the scientific research on the effectiveness of Artemisia, the key herbal ingredient in CVO.

The eagerness to import, test, and use CVO illustrated several aspects of agency surrounding COVID-19. First, it demonstrated a desire to find Africabased solutions that resonate with local populations, legitimate and conserve local practices around the use of traditional medicine, and decrease reliance on the West. These Africa-based solutions to complex health and development problems emphasize local traditions, cultural practices, and indigenous institutions; they do not merely imitate the West (Ayittey 2014). They recognize the widespread role of traditional, herbal medications in health management in Africa. These solutions often strive to merge traditional approaches with biomedical knowledge, by incorporating traditional healers into programs on tuberculosis control, AIDS treatment adherence, and mental health referrals. One Tanzanian health expert explained: "Give the traditional healer a screening tool ... and tell them, 'If you see this and this and this, refer the patient to the hospital" (interview, Dodoma, December 19, 2019). An official in WAHO also explained that in the response to emergency health issues, "citizens in member states have a cultural preference to use traditional medicine for their health needs, often with conventional medical care to account for how diseases imbalance their minds, 
bodies, and souls" (interview, Bobo-Dioulasso, August 2019). These perspectives recognize the ubiquity of traditional care providers and the widespread use of these alternative medicines, as well as how traditional healers frame health in cultural and spiritual ways that may resonate better with local populations (Olsen \& Sargent 2017).

Locally developed treatments also may ensure greater patient treatment access, particularly since transnational pharmaceutical companies that develop most therapeutics and vaccines determine pricing, marketing, and distribution. Regionally developed products could help decrease reliance on global trade regimes that disadvantage lower-income countries (Gleeson et al. 2019). In addition, leaders may want to claim credit for and build constituencies around nationally derived solutions to health problems, illustrating how agency may be manifest in ways that cater to domestic political constituencies (Murray-Evans 2015). For example, former Gambian president Yahya Jammeh supported an herbal AIDS cure, partly to win political favors with Muslim and traditional healers and to tap into ministerial resentment over perceived donor control of AIDS programs (Cassidy \& Leach 2009).

Second, the development and distribution of CVO indicates heterogeneity among African actors and debates within the emerging epistemic community. In May 2020, ECOWAS publicly acknowledged that the organization did not endorse CVO as an official remedy to COVID-19, while it continued to embrace the use of traditional medicines (West African Health Organization 2020). Similarly, the AU provided no definitive support for CVO, stating that it was in conversations with the Malagasy government regarding the scientific data used to assess CVO's efficacy. This action aligned with an Africa CDC statement on herbal remedies that both acknowledges their widespread use and necessitates their evaluation for safety and efficacy prior to AU endorsement for use by medical officials or the public (African Union 2020h). The WHO warned African countries not to use or rely on CVO, because it had not been subjected to WHO regulatory standards of quality and efficacy (WHO-AFRO 2020b). In response, President Rajoelina criticized the WHO for challenging the efficacy of CVO, stating that if a European country had discovered CVO, there would be less doubt about its effectiveness (France 24 2020). Within a few months, though, some African countries pulled support for the treatment. In early July 2020, Nigeria's National Institute of Pharmaceutical Research and Development reported that there was no evidence for the efficacy of the CVO treatment (Tih 2020), and the Congo suspended use of the treatment. By late July, Madagascar reported over ten thousand COVID-19 cases and a growing health crisis (Africa News 2020a). These actions show that epistemic communities-both globally and within the region-can face internal debates about ways of knowing. This point was also evident in the United States, particularly with scientific skepticism over Food and Drug Administration approval for convalescent plasma treatment and President Trump's insistence on the efficacy of hydroxychloroquine against the virus (Kravitz 2020; Johnson et al. 2020). 
Finally, tensions over the use and validity of CVO highlight how reliance on external donor partners such as the WHO may circumscribe what is defined as a "legitimate" response to a public health outbreak. Regional organizations such as WAHO and the Africa CDC face external pressures to follow an accepted scientific research protocol endorsed by the WHO. As one respondent explained, WAHO has a comparative advantage as an institution in traditional medicine expertise, yet funding partners are often not interested in traditional medicine and often threaten to withhold funding or devalue the effectiveness of traditional medicine (interview, Director of the Department of Health Care Services, WAHO, Bobo-Dioulasso, August 19, 2019). Another practitioner in WAHO referenced how, during the Ebola outbreak, donors minimized the positive results yielded from traditional medicine (interview, WAHO Director of External Relations, Bobo-Dioulasso, August 18, 2018). More broadly, donor funding shapes the parameters of health research, leading African scientists to focus on communicable diseases and biomedical solutions (interview, Kwame Nkrumah University of Science and Technology professor, Accra, May 4, 2017). These dispositions and, at times, misaligned priorities between African health actors and their funding partners illustrate the push and pull dynamics of agency and the ways that competing interests may constrain innovation or possible solutions to health problems. At the same time, the participation of African agents in these relations indicates the point that purposive agents do not always challenge the status quo (Hurt 2013).

\section{Agency Manifest in State-Civil Society Collaboration}

Across the continent, there have been different policy approaches to contact tracing, social distancing, and testing. As part of those policies, models of state-civil society collaboration have varied significantly. This fact indicates that even within epistemic communities and a context that values African solidarity, there are differences about how to address issues. We focus on four general patterns in state-civil society collaboration, although no doubt others exist. These responses show African players as agents in the context of the pandemic, although civil society organizations may have limited autonomy because they often do not directly negotiate with multilateral institutions.

The first example of an agentic response was state-civil society collaboration that relied on religious, traditional, and/or community-based organizations for information sharing, adoption of health behaviors, and/or economic impact mitigation. In Ghana, Christian and Muslim religious institutions quickly mobilized after the government announced a lockdown. They capitalized on their knowledge about communities, their organizational structures, and their overall respected leadership to organize food distribution in neighborhoods affected by the lockdown and to urge citizens to follow public health advice. They worked with the government to disseminate messages around handwashing and social distancing, and some churches even donated to the government's emergency COVID-19 fund 
(Kale-Dery \& Abbey 2020). Similarly, South African community organizations built on their experiences with service delivery and advocacy strategies from years of mobilization on issues such as AIDS. Many formed partnerships with local government officials to advocate for and disseminate food and supplies provided by the national government (CAN Activists 2020). Community groups disseminated information on COVID-19 to the estimated 5.7 million South Africans living with HIV and AIDS, and they surveyed these individuals about their access to HIV (and tuberculosis) medications during the crisis (Pikoli 2020). These data enabled civil society to make normative claims to the government and donors about the right to health through medication access (Global Fund 2020).

Second, agency was evident when state-civil society collaborative efforts tapped into epistemic knowledge gained from prior epidemics. In Ghana, religious institutions used lessons learned about effective health messaging from the "Compassion Campaign" against AIDS in 2000 (Patterson 2011) and the Ebola prevention campaign in 2014-15 (interview, Christian Council of Ghana Official, Accra, April 18, 2017). In Liberia, the government worked with community-based contact tracers as it had in the Ebola outbreak to test for and detect coronavirus cases. Over time, though, community mobilization became problematic, because the government lacked sufficient funds to pay some tracers and the general population questioned the urgency of the response because of the relatively low number of COVID-19 deaths (Maxmen 2020). Liberia serves as an illustration of how mobilization based on prior experiences may still face challenges of low state capacity and public distrust.

Third, some collaborations took the form of civil society actions that creatively addressed the pandemic and recognized local expertise. For example, when the Nigerian government accepted help from Chinese medical teams, health worker associations protested. In addition to concern that the foreign workers might transmit the virus, they questioned the need for Chinese advice, since local health-care workers had significant experience with infectious disease outbreaks such as Lassa fever, AIDS, polio, and Ebola (Asiedu 2020b). Their efforts recognized an African epistemic community that includes civil society expertise. In Ghana, creative approaches included partnerships with the U.S.-based private startup company Zipline to deliver testing kits to rural areas via drones (Reuters 2020b). This new approach reduced sample transport time by hours, facilitating quicker contact tracing and care for those who were ill. Partnerships with the private sector also included Facebook's engagement with over twenty countries to set up COVID-19 information centers (Mugisha 2020). These efforts also increased these national governments' agency and autonomy.

More broadly, some civil society voices called for using African expertise to promote greater African self-reliance. In mid-April 2020, one hundred African intellectuals penned an open letter to African leaders, part of which directly challenged the continent's "systemic dependence." Echoing ideas of solidarity, they portrayed the pandemic as providing space for the continent to "break with the outsourcing of our sovereign prerogatives," develop 
"institutions on the basis of our specificities and our resources," and promote "endogenous development" (African Arguments 2020). Emancipatory in tone, the letter challenged global structures and called for governance that addressed the needs of the population. African economic leaders have shared these sentiments, including African Development Bank president Akin Adesina, who called on national governments to double the amount of spending on the health sector as a long-term mitigation and response strategy.

A final pattern indicated agency among government officials who responded, though with limited (if any) civil society input. Uganda and Tanzania provide examples, although each had a different approach to the virus itself. In Uganda, government health officials built on epistemic knowledge gained from prior Ebola outbreaks and preparation for the potential spread of Ebola from the Democratic Republic of Congo in 2018-19. They established a swift, comprehensive response that included high levels of testing, aggressive contact tracing, a curfew, limits on travel, and closure of many public spaces. However, the lack of civil society input (particularly from human rights and women's groups) in the response design led to policies that with time undermined access to health centers and food, contributing to increased maternal mortality and hunger (Lirri 2020). Although praised by WHO and donors, the government's heavy-handed approach echoed its use of neighborhood security groups to police behavior and district officials' pressure for youth to participate in abstinence-only AIDS programs (interview, community advocate, Kampala, May 28, 2018). In Tanzania, the government challenged the WHO and donors who criticized its limited lockdown, support for CVO, and alleged underreporting of cases, saying these critiques were "imperialist." It downplayed concerns from other African states about its lack of case reports and its support for public gatherings such as church services (Kiruga 2020). Journalists who reported criticisms of the response faced crackdowns, and civil society mobilization on the pandemic was limited. The government's agency challenged notions of homogeneity in African responses, as Tanzania pursued its own path in the pandemic response. It also reflected the rise of personalized and authoritarian rule during an election year (Paget \& Kwayu 2020) and a historic pattern of relatively muted civil society responses to state-directed development (K. Phillips 2018).

\section{Conclusion}

COVID-19 exacerbates the already volatile and diverse political, economic, and socio-cultural terrain of Africa. While the narrative in March 2020 suggested that the situation in Africa would significantly worsen, African actors have recognized the need for a networked response to the crisis. Though at the time of this writing, the pandemic was ongoing, the response highlights the potential of agency and interconnectedness within the continent. In practice, solidarity is not absolute, as divisions over PVO and various 
state-civil society models of collaboration illustrate. However, African actors have maneuvered at the continental and national levels to respond. The pandemic illustrates the inherent desire for solidarity from African publics and governments, as well as the ability of agents to build on present knowledge and culturally relevant tools to organize creatively everything from continent-wide initiatives to promote testing to nationally endorsed food distribution through civil society partners. As such, it is an African response that, while often tied to external actors, also recognizes the unique experiences of the continent in outbreaks and health more broadly.

Additionally, what our analysis of agency uncovers is that while there are significant attempts at harmonization and varied national level responses, the agency of actors is conditioned by different forms of governance, health systems, and infrastructure across the continent. While our analysis highlights and acknowledges the important ways in which African actors have collaborated to shape and develop a truly continental response, it is also important to note that the pandemic has exacerbated already tenuous living conditions for vulnerable populations, emboldened certain repressive leaders and regimes, and placed tremendous stress on already fragile health infrastructures across the continent. Our analysis serves as a starting point to assess the scope of cooperation and agency among heterogeneous actors.

Future areas of research could draw comparative lessons on how African state-civil society collaboration plays out in various global health outbreaks, charting the different forms of adaptation in global health policy from Ebola and COVID-19. Scholars could question the strategies of both state and nonstate actors as they build and react to emerging norms of cooperation and solidarity on health, particularly through regional organizations. In this context, scholars could investigate what the enduring role of international donors might be in the face of rising norms of African solidarity and collective agency. Finally, future studies should investigate how an African agency rooted in epistemic communities and solidarity is evident in other issue areas such as climate change.

\section{Acknowledgments}

The authors appreciate the helpful comments from four anonymous reviewers and the editors which have significantly improved the paper. Funding for portions of the research was provided by the authors' home institutions, as well as the Fulbright U.S. Scholar program. All errors remain ours.

\section{References}

Acharya, Amitav. 2004. "How Ideas Spread: Whose Norms Matter? Norm Localization and Institutional Change in Asian Regionalism." International Organization 58 (2): 239-75. 
2011. "Norm Subsidiarity and Regional Orders: Sovereignty, Regionalism, and Rule-Making in the Third World." International Studies Quarterly 55 (1): 95-123.

Adkins, Travis L., and Jeffery Smith. 2020. "Will COVID-19 Kill Democracy?” Foreign Policy September 18.

Adler, Emanuel, and Steven Bernstein. 2005. "Knowledge in Power: The Epistemic Construction of Global Governance." In Power in Global Governance, edited by Michael Barnett and Raymond Duvall, 294-318. New York: Cambridge University Press.

Africa CDC. 2020. "Africa Centres for Disease Control and Prevention Strategic Plan Strategy 2017-2021.”

Africa News. 2020a. "Madagascar COVID-19: Caseload Hits 10,000 Mark.” July 29.

17.

African Arguments. 2020. "COVID-19: An Open Letter from African Intellectuals to Africa's Leaders.” April 16.

African Union. 2020a. "Africa CDC and Mastercard Foundation Partner to Deliver One Million Test Kits, Deploy 10,000 Community Health Workers for COVID-19 Response."

—. 2020b. "Africa CDC, FIND Partner to Build Capacity for COVID-19 Rapid Diagnostic Tests in Africa."

- 2020c. "The Africa Centres for Disease Control and Prevention (Africa CDC)

Partners with the United Nations Development Programme (UNDP) to Strengthen Africa's Response to COVID-19."

—. 2020d. "Africa Joint Continental Strategy for COVID-19 Outbreak." . 2020e. "African Union and Africa Centres for Disease Control and Prevention

Launch Partnership to Accelerate COVID-19 Testing: Trace, Test, and Track.”

—. 2020f. "African Union Commission Launches Consortium for COVID-19 Vaccine Clinical Trial."

—. 2020g. "Impact of the Coronavirus (COVID-19) on the African Economy."

. 2020h. "Statement on Herbal Remedies and Medicines for Prevention and

Treatment of COVID-19."

Al Jazeera. 2020a. “Coronavirus: What Is Madagascar's 'Herbal Remedy' CovidOrganics?" May 5.

—. 2020b. "World Reacts to Trump Withdrawing WHO Funding." April 15.

Anderson, Emma-Louise. 2018. "African Health Diplomacy: Obscuring Power and

Leveraging Diplomacy through Shadow Diplomacy.” International Relations 32 (2): 194-217.

Anderson, Emma-Louise, and Amy S. Patterson. 2017. Dependent Agency in the Global Health Regime. New York: Palgrave Macmillan.

Asiedu, Kwasi Gyamfi. 2020a. "China Has Failed to Convince Anyone Videos of Africans Being Evicted Is Just a 'Misunderstanding.'” Quartz Africa. April 14.

— 2020b. "China Wants to Help Africa Fight Coronavirus But Not Everyone Is Welcoming." Quartz Africa. April 8.

Ayittey, George. 2014. "African Solutions to African Problems-The Real Meaning." January 3.

Ayoob, Mohammed. 2002. "Inequality and Theorizing in International Relations: The Case of Subaltern Realism." International Studies Review 4 (3): 27-48.

Balogun, Emmanuel. Forthcoming. Convergence and Agency in West Africa: RegionBuilding in ECOWAS. London: Routledge. 
Bareebe, Gerald. 2018. "The Pan-African Solidarity Norm." In African Actors in International Security, edited by Katharina P. Coleman and Thomas K. Tieku, 73-93. Boulder, Colorado: Lynne Rienner.

Barigazzi, Jacopo, David Herszenhorn, and Simon Marks. 2020. "In Search of Allies, EU Turns to Africa." Politico. February 26.

Barnes, Amy, Garrett Brown, and Sophie Harman. 2015. Global Politics of Health Reform in Africa: Performance, Participation and Policy. New York: Palgrave Macmillan.

Bayart, Jean-Francois. 2000. "Africa and the World: A History of Extraversion." African Affairs 99 (395): 217-67.

Benton, Adia. 2015. HIV Exceptionalism: Development through Disease in Sierra Leone. Minneapolis: University of Minnesota Press.

Bertrand, Natasha, Gabby Orr, Daniel Lippman, and Nahal Toosi. 2020. "Pence Task Force Freezes Coronavirus Aid amid Backlash.” Politico. March 31.

Brass, Jennifer. 2016. Allies or Adversaries: NGOs and the State in Africa. New York: Cambridge University Press.

Broadbent, Alex, and Benjamin T. H. Smart. 2020. "Why a One-Size-Fits-All Approach to COVID-19 Could Have Lethal Consequences." The Conversation. March 23.

Brown, William. 2012. "A Question of Agency: Africa in International Politics." Third World Quarterly 33 (10): 1889-1908.

Brown, William, and Sophie Harman, eds. 2013. African Agency in International Politics. London: Routledge.

Burnet, Jennie. 2008. "Gender Balance and the Meanings of Women in Governance in Post-Genocide Rwanda." African Affairs 107 (428): 361-86.

Campbell, Charlie. 2020. “'A Crime against Humanity.' Why Trump's WHO Funding Freeze Benefits Nobody.” Time. April 15.

CAN Activists. 2020. "Cape Town Together: Organising in a City of Islands." Daily Maverick. June 30.

Carmody, Pádraig, and Peter Kragelund. 2016. "Who Is in Charge? State Power and Agency in Sino-African Relations.” Cornell International Law Journal 49 (1): 1-23.

Cassidy, Rebecca, and Melissa Leach. 2009. "Science, Politics and the Presidential AIDS ‘Cure'.” African Affairs 108 (433): 559-80.

Chabal, Patrick, Ulf Engle, and Leo de Haan, eds. 2007. African Alternatives. Leiden, Netherlands: Brill.

Chipaike, Ronald, and Matarutse Knowledge. 2018. "The Question of African Agency in International Relations." Cogent Social Sciences 4 (1): 1-16.

Clapham, Christopher. 1996. Africa in the International System. New York: Cambridge University Press.

Du Plessis, Max. 2012. "Implications of the AU Decision to Give the African Court Jurisdiction over International Crimes." Institute for Security Studies Papers 235: $1-16$.

Dunn, Kevin, and Timothy Shaw. 2001. Africa's Challenge to International Relations Theory. New York: Palgrave Macmillan.

Editors. 2020. "Global Collaboration for Health: Rhetoric versus Reality." Lancet 396 (September 12): 735.

Edozie, Rita Kiki. 2017. "Pan" Africa Rising: The Cultural PoliticalEconomy of Nigeria's Africapitalism and South Africa's Ubuntu Business. New York: Palgrave Macmillan.

European Union. 2020. "Coronavirus Global Response Summit: External Response Factsheet."

Fisher, Jonathan. 2013. “'Image Management' and African Agency: Ugandan Regional Diplomacy and Donor Relations under Museveni." In African Agency 
in International Politics, edited by William Brown and Sophie Harman, 97-113. London: Routledge.

France 24. 2020. "Madagascar's President Defends Controversial Homegrown COVID19 Remedy.” May 12.

Freedom House. 2020. "Countries and Territories."

Gilbert, Marius, Giulia Pullano, Francesco Pinotti, Eugenio Valdano, Chiara Poletto, Pierre-Yves Boëlle, Eric D’Ortenzio, Yazdan Yazdanpanah, Serge Paul Eholie, Mathias Altmann, Bernardo Gutierrez, Moritz U G Kraemer, and Vittoria Colizza. 2020. "Preparedness and Vulnerability of African Countries against COVID-19: A Modelling Study.” Lancet 395 (10227): 871-77.

Glas, Aarie. 2018. "African Union Security Culture in Practice: African Problems and African Solutions.” International Affairs 94 (5): 1121-38.

Glas, Aarie, and Emmanuel A. Balogun. 2020. "Norms in Practice: People-Centric Governance in ASEAN and ECOWAS." International Affairs 96(4): 1015-32.

Gleeson, Deborah, Joel Lexchin, Ronald Labonté, Belinda Townsend, Marc-André Gagnon, Jillian Kohler, Lisa Forman, and Kenneth C. Shadlen. 2019. "Analyzing the Impact of Trade and Investment Agreements on Pharmaceutical Policy: Provisions, Pathways and Potential Impacts." Global Health 15 (78).

Global Fund. 2020. "COVID-19 Overview."

Graboyes, Melissa. 2015. The Experiment Must Continue: Medical Research and Ethics in East Africa, 1940-2014. Athens, Ohio: Ohio University Press.

Guardian. 2020. “Burundi Expels WHO Coronavirus Team as Election Approaches." May 14. Haas, Richard. 1992. "Introduction: Epistemic Communities and International Policy Coordination." International Organization 46 (1): 1-35.

Hershey, Megan. 2019. Whose Agency? The Politics and Practice of Kenya's HIV-Prevention NGOs. Minneapolis: University of Minnesota Press.

Houttuin, Saskia, and Joost Bastmeijer. 2020. "Tanzania Doctors Sound Alarm over Hidden Coronavirus Cases.” The New Humanitarian. May 14.

Hurt, Stephen. 2013. "African Agency in World Trade Undermined? The Case of Bilateral Relations with the European Union.” In African Agency in International Politics, edited by William Brown and Sophie Harman, 29-64. London: Routledge.

International Monetary Fund. 2020. "Serving Member Countries: COVID-19 Emergency Financial Assistance."

Johnson, Carolyn, Laurie McGinley, Josh Dawsey, and Seung Min Kim. 2020. "Trump Touts FDA's Emergency Authorization of Convalescent Plasma as Historic Breakthrough, but Scientists are Doubtful.” Washington Post. August 23.

Kale-Dery, Severious, and Emelia Ennin Abbey. 2020. "Churches Suspend Activities, Move to Contain Spread of COVID-19." Daily Graphic. March 17.

Kimeria, Ciku. 2020. "Coronavirus: Africa's Biggest Airline Is Starting to Cut Back Its China Flights.” Quartz Africa. February 8.

Kiruga, Morris. 2020. "Coronavirus: Tanzania's Handling of Pandemic Raises Eyebrows.” The Africa Report. May 15.

Kohnert, Dirk. 2018. "Trump's Tariff Impact on Africa and the Ambiguous Role of African Agency." Review of African Political Economy 45 (157): 451-66.

Kravitz, Richard. "When Trump Pushed Hydroxychloroquine to Treat COVID-19, Hundreds of Thousands of Prescriptions Followed despite Little Evidence that It Worked.” The Conversation. July 9.

Lawler, Dave. 2020. "Global Coronavirus Vaccine Initiative Launches without U.S. or China." Axios. September 24. 
LeVan, Carl. 2010. "The Political Economy of African Responses to the U.S. Africa Command." Africa Today 57 (1): 3-23.

Lirri, Evelyn. 2020. "How Uganda's Tough Approach to COVID-19 Is Hurting Its Citizens." Telegraph. August 26.

Lonsdale, John. 2000. "Agency in Tight Corners: Narrative and Initiative in African History." Journal of African Cultural Studies 13 (1): 5-16.

Marks, Simon, and Abdi Latif Dahir. 2020. "Africa, Intertwined with China, Fears Coronavirus Outbreak.” New York Times. February 6.

Maxmen, Amy. 2020. "Ebola Prepared These Countries for Coronavirus-But Now Even They Are Floundering." Nature. July 21.

Mbali, Mandisa. 2013. South African AIDS Activism and Global Health Politics. New York: Palgrave MacMillan.

Mobarak, Ahmed Mushfiq, and Zachary Barnett-Howell. 2020. "Poor Countries Need to Think Twice about Social Distancing." Foreign Policy. April 10.

Mohan, Giles. 2015. "Queuing Up for Africa: The Geoeconomics of Africa's Growth and the Politics of African Agency." IDPR 37 (1): 45-52.

Mohan, Giles, and Ben Lampert. 2012. "Negotiating China: Reinserting African Agency into China-Africa Relations." African Affairs 112 (446): 92-110.

Mohan, Giles, and Marcus Power. 2013. "New African Choices? The Politics of Chinese Engagement." Review of African Political Economy 35 (115): 23-42.

Morgenthau, Hans. 1985. Politics among Nations: The Struggle for Power and Peace. New York: Alfred Knopf.

Mugisha, Emmanuel. 2020. "Facebook Launches Covid-19 Information Centers in Rwanda, Other African Countries." The New Times. April 27.

Murithi, Tim. 2009. "The United Nations: Between Paternalism and Partnership." In A New Scramble for Africa? Imperialism, Investment and Development, edited by Roger Southall and Henning Melber, 340-51. Durban, South Africa: University of KwaZulu Natal Press.

Murray-Evans, Meg. 2015. "Regionalism and African Agency: Negotiating an Economic Partnership Agreement between the European Union and SADC-Minus." Third World Quarterly 36 (10): 1845-65.

Nordling, Linda. 2020. "The Pandemic Appears to Have Spared Africa So Far. Scientists Are Struggling to Explain Why." Science. August 11.

Nyabiage, Jevans. 2020. "Coronavirus: African Leaders Stand Up for WHO, Tedros after Criticism from Donald Trump." South China Morning Post. April 9.

Olsen, William, and Carolyn Sargent. 2017. African Medical Pluralism. Bloomington: Indiana University Press.

Paget, Dan, and Aikande Element Kwayu. 2020. "COVID-19 Is Casting Magufuli in the Worst Light, in an Election Year.” The Conversation. May 13.

Patterson, Amy S. 2011. The Church and AIDS in Africa: The Politics of Ambiguity. Boulder, Colo.: First Forum Press.

- 2018. Africa and Global Health Governance: Domestic Politics and International Structures. Baltimore, Md.: Johns Hopkins Press.

Penney, Joe. 2020. "Coronavirus Starts in China but Europe Became the Hub for Its Global Spread." The Intercept. April 2.

Phillips, John. 2018. "Who's in Charge of Sino-African Resource Politics? Situating African State Agency in Ghana." African Affairs 118 (470): 101-24.

Phillips, Kristin. 2018. An Ethnography of Hunger: Politics, Subsistence, and the Unpredictable Grace of the Sun. Bloomington: Indiana University Press. 
Picheta, Rob. 2020. "WHO Chief Blasts 'Lack of Leadership' and Calls for Global Unity as Coronavirus Cases Mount Worldwide.” CNN News. July 10.

Pikoli, Zukiswa. 2020. "Civil Society Health Organisations Launch COVID-19 Survey." Daily Maverick. April 21.

Reuters. 2020a. "China in the Driver's Seat amid Calls for Africa Debt Relief." April 12. . 2020b. "Ghana Turns to Drones to Enable Faster Coronavirus Testing." April 20.

Rushton, Simon. 2015. "The Politics of Researching Global Health Politics." International Journal of Health Policy and Management 4 (5): 311-14.

Schraeder, Peter. 2018. “'Making America Great Again' against the Backdrop of an 'Africa Rising'? The Trump Administration and Africa's Marginalization within U.S. Foreign Policy.” Journal of Diplomacy and International Relations 20 (1): 98-117.

Shajalal, Mohon, Junfang Xu, Jun Jing, Madeleine King, Jie Zhang, Peicheng Wang, Jennifer Bouey, and Feng Cheng. 2017. "China's Engagement with Development Assistance for Health in Africa." Global Health Research and Policy 2 (24): 1-9.

Shesgreen, Deirdre. 2020. "Senegal's Quiet COVID Success: Test Results in 24 Hours, Temperature Checks at Every Store, No Fights Over Masks.” USA Today. September 6 .

Star. 2020. "Kenya Airways Bows to Pressure, Suspends Flights to China.” January 31. Swidler, Ann, and Susan Watkins. 2017. A Fraught Embrace: The Romance and Reality of AIDS Altruism in Africa. Princeton, New Jersey: Princeton University Press.

Taylor, Ian. 2015. "The Good, the Bad and the Ugly: Agency as Corruption in the SinoNigerian Relationship." In Africa and China: How Africans and Their Governments Are Shaping Relations with China, edited by Aleksandra Gadzala, 27-44. New York: Rowman \& Littlefield.

Tieku, Thomas Kwasi. 2013. "Exercising African Agency in Burundi via Multilateral Channels: Opportunities and Challenges." Conflict, Security Ev Development 13 (5): 513-35.

- 2017. Governing Africa: 3D Analysis of the African Union's Performance. New York: Rowman \& Littlefield.

Tieku, Thomas Kwasi, and Tanzeel F. Hakak. 2014. "A Curious Case of Hybrid Paternalism: Conceptualizing the Relationship between the UN and AU on Peace and Security." African Conflict and Peacebuilding Review 4 (2): 129-56.

Tih, Felix. 2020. "Nigeria: Madagascar's Herbal Drink Cannot Cure COVID-19." Anadolu Agency, July 7.

UNDP. 2020. "COVID-19 Socioeconomic Impact in Africa."

UNICEF. 2020. "Coronavirus Disease (COVID-19) Response: Donors and Partners."

U.S. Department of State. 2020. "The United States is Leading the Humanitarian and Health Response to COVID-19."

Wald, Patricia. 2008. Contagious: Cultures, Carriers and the Outbreak Narrative. Durham, North Carolina: Duke University Press.

Webb, James. 2014. The Long Struggle Against Malaria in Tropical Africa. Cambridge: Cambridge University Press.

West African Health Organization. 2020. "ECOWAS Commission and WAHO Refute Alleged Endorsement of CVO Medication."

Westcott, Nicholas. 2019. "The Trump Administration's Africa Policy." African Affairs 18 (472): 737-49.

Whitaker, Beth Elise, and John Clark. 2018. Africa's International Relations: Balancing Domestic and Global Interests. Boulder, Colorado: Lynne Rienner. 
WHO. 2020a. "COVID Clinical Community of Practice- Africa Region.”

—. 2020b. "COVID-19 Strategic Response Plan in the WHO African Region." WHO-AFRO. 2020a. "African Countries Move from COVID-19 Readiness to Response as Many Confirm Cases."

. 2020b. "WHO Supports Scientifically-Proven Traditional Medicine."

Williams, Alexandria. 2020. "African Countries Are Evacuating Some Students over Coronavirus, But Most Hesitate." Quartz Africa. March 2.

World Bank. 2020. "Africa Development Indicators."

Youde, Jeremy. 2012. Global Health Governance. Medford, Massachusetts: Polity Press.

Zeleza, Paul Tiyambe. 2013. "Obama's Africa Policy: The Limits of Symbolic Power." African Studies Review 56 (2): 165-78.

\section{Note}

1. For other examples of work on Africa in global health governance, see Anderson \& Patterson 2017; Patterson 2018; Balogun forthcoming; Barnes, Brown, \& Harman 2015; Benton 2015; Hershey 2019; Swidler \& Watkins 2017. 